\title{
A Founder Mutation in French-Canadian Families with X-linked Hereditary Neuropathy
}

\author{
Nicolas Dupré, Louise Cossette, Collette K. Hand, Jean-Pierre Bouchard, \\ Guy A Rouleau, Jack Puymirat
}

\begin{abstract}
Background: The aim of the present study was to identify the mutations in the connexin 32 gene in French-Canadian families with X-linked Charcot-Marie-Tooth disease (CMTX). Methods: Molecular analysis was performed by nonisotopic single strand conformation polymorphism (SSCP) analysis and sequencing. Clinical evaluation was carried out according to the scale defined by the European Hereditary Motor and Sensory Neuropathy Consortium. Results: In one family, the mutation Arg142Trp was located in the transmembrane domain III whereas, in four other families we identified a novel mutation (Ser26Trp) located in the transmembrane domain I of the connexin 32 gene. Haplotype analysis revealed that these four families are related and suggests a founder mutation. Sixteen patients from these four families were studied. As expected, all the affected males were more clinically affected than the females and all affected patients exhibited some electrophysiological characteristics of demyelination. Conclusion: Our study suggests that the Ser26Trp mutation may cause a primary demyelinating neuropathy that is not associated with a specific clinical phenotype. We also find evidence that the majority of kindreds share a common ancestor.
\end{abstract}

RÉSUMÉ: Effet fondateur chez des familles canadiennes-françaises atteintes de neuropathie héréditaire liée à l'X. Introduction: Le but de cette étude était d'identifier les mutations du gène de la connexine 32 chez des familles canadiennes-françaises atteintes de la maladie de Charcot-Marie-Tooth liée à l'X (CMTX). Méthodes: L'analyse moléculaire a été faite par polymorphisme de conformation d'ADN simple brin non isotopique et séquençage. L'évaluation clinique a été effectuée selon l'échelle définie par le Consortium HMSN Européen. Résultats: Dans une famille, la mutation Arg142Trp a été localisée dans le domaine transmembranaire III alors que chez quatre autres familles, nous avons identifié une nouvelle mutation (Ser26Trp) localisée dans le domaine transmembranaire I du gène $\mathrm{Cx} 32$. L'analyse des haplotypes a montré que ces quatre familles sont apparentées et suggère qu'il s'agit d'une mutation fondatrice. Seize patients de ces quatre familles ont été étudiés. Tel que prévu, tous les hommes atteints étaient plus sévèrement atteints que les femmes et tous les patients atteints présentaient des caractéristiques électrophysiologiques de démyélinisation. Conclusion: Notre étude suggère que la mutation Ser26Trp peut causer une neuropathie démyélinisante primaire qui n'est pas associée à un phénotype clinique spécifique. Nous avons également des données qui démontrent que la majorité des familles ont un ancêtre commun.

Can. J. Neurol. Sci. 2001; 28: 51-55

$\mathrm{X}$-linked Charcot-Marie-Tooth disease (CMTX) is a clinically heterogenous group of diseases with both dominant and recessive inheritance. The dominant form (CMT $\chi 1)$ has been linked to mutations in the connexin $32(\mathrm{C} \chi 32)$ gene, which codes for a 283 amino acid gap junction protein found in myelinated peripheral nerve. ${ }^{1}$ Over 130 different mutations in C 732 gene associated with CMTX have been identified (for review see Nelis et $\mathrm{al}^{2}$ ). The majority of these mutations cause amino acid substitutions, whereas a minority result in the formation of either premature stop codons or cause frame shift mutation. ${ }^{3-10}$ Furthermore, five small deletion mutations have also been reported ${ }^{1,11}$ The phenotypic manifestations have been reported in CMTX families where the mutation is unknown ${ }^{12,13}$ or known. $6,14,15$ These studies reveal that males have more wasting and weakness than females. Motor nerve conduction velocities (MNCV) were significantly slower in males than in females. Because of the number of mutations that cause CMTX, the question which remains to be answered is whether a specific

From the Laboratoire de Recherche en Génétique Humaine, CHU Laval, (ND, LC, JP); Département des Sciences Neurologiques, Hôpital Enfant-Jésus, Québec (J-PB); and

Center for Research in Neuroscience, McGill University and the Institut de Recherche, Hôpital Général de Montréal, Montréal, (CKH, GAR)Canada.

ReCeIVEd August 30, 2000. ACCEPTED INFINALFORM November 27, 2000

Reprint requests to: Jack Puymirat. Laboratoire de Recherche en Génétique Humaine, CHU Laval, 2705 Blvd Laurier, Ste-Foy, Québec, G1V4G2, Canada. 
mutation may lead to a specific phenotype. Recently, genotype/phenotype correlation studies in families with different mutations had suggested that the type and the position of the mutations may lead to specific phenotypes. ${ }^{15,16}$

In the present study, we identified a novel mutation located in the transmembrane domain I in the $\mathrm{C} \chi 32$ gene. This mutation was observed in four of five French-Canadian families with a clinical diagnosis of CMTX1. Haplotype analysis revealed that these families are related and suggests a founder mutation. This mutation is associated with electrophysiological characteristics of demyelination and does not lead to a specific clinical phenotype.

\section{MATERIALAND METHODS}

The affected subjects were studied at the adult Neuromuscular Disease Clinic of the "Institut de Réadaptation en Déficience Physique du Québec" (IRDPQ). All the patients were examined by the same author (J.P.).

The family pedigrees were reconstructed in order to establish the pattern of inheritance. A standard clinical and electrophysiological evaluation was carried out in all families. The criteria adopted, whether or not to include an affected subject as CMT-X1, were: no male to male transmission, females less affected than males and moderate decreased motor conduction velocity $(22<$ motor neuron conduction velocity $(\mathrm{MNCV})<40$ $\mathrm{m} / \mathrm{s}$ for males and MNCV $>30 \mathrm{~m} / \mathrm{s}$ for females).

\section{Clinical features}

The age at onset for each patient was determined by asking the patients or the parents about the age at which the first symptoms appeared.

Muscle weakness was graded by manual testing according to the Medical Research Council scale. The functional handicap was assessed according a nine-point functional disability scale (FDS) as described by Birouk et $\mathrm{al}^{17} 0=$ normal; $1=$ normal, but presence of cramps and fatigability; 2 = inability to run; $3=$ walking difficult but still possible unaided; $4=$ able to walk with a cane; $5=$ able to walk with crutches; $6=$ able to walk with a walker; $7=$ wheelchair bound; $8=$ bedridden.

\section{Electrodiagnostic procedures}

All propositi and most of their relatives participating in the study underwent nerve conduction studies using a NihonKohden (Neuropack-2XPD) or a TECA TD 20 model. Motor conduction velocities were obtained for the median and ulnar nerves. Sensory nerve action potentials (SNAPs) were recorded, following antidromic stimulation of the median and ulnar nerves, by ring electrodes on the first and fourth fingers. The amplitude of the motor and sensory responses were then computed.

\section{Molecular analysis}

Genomic DNA was extracted from venous blood samples according to classical procedure. The $17 \mathrm{p} 11.2$ duplication was excluded in all these families by southern blot analysis using VAW409R3a probe as described. ${ }^{18}$ Identification of mutation in the $\mathrm{C} \chi 32$ gene was performed by nonisotopic single strand conformation polymorphism analysis according to the procedure described by Rouger et al. ${ }^{10}$ The $\mathrm{C} \chi 32$ coding sequence was amplified with a different set of primers in a Perkin Elmer 9600 apparatus, under the following conditions: $96^{\circ} \mathrm{C}$ for $5 \mathrm{~min}$ (hotstart), $94^{\circ} \mathrm{C}$ for $10 \mathrm{~min}$ for $1 \mathrm{cycle} ; 96^{\circ} \mathrm{C}$ for $15 \mathrm{sec}, 58^{\circ} \mathrm{C}$ and $72^{\circ} \mathrm{C}$ for $15 \mathrm{sec}$ (35 cycles). Polymerase chain reaction (PCR) fragments were precipitated with $0.3 \mathrm{M}$ ammonium acetate and ethanol $2 \mathrm{~V} / \mathrm{V}$, denatured at $96^{\circ} \mathrm{C}$ for $5 \mathrm{~min}$ and electrophoresed in a non denaturing 0.5X Hydrolink MDE acrylamide/0.6X TBE

Table 1: Haplotype analysis of 10 French-Canadian males and 4 CMTX1 males from four different families with Ser26Trp mutation.

\begin{tabular}{|c|c|c|c|c|c|c|c|}
\hline Marker & DXS1216 & DXS1275 & DXS8031 & DXS8046 & DXS983 & DXS8092 & DXS986 \\
\hline Position & $53.6 c M$ & $55.8 \mathrm{cM}$ & $55.8 \mathrm{cM}$ & $56.3 \mathrm{cM}$ & $56.3 \mathrm{cM}$ & $57.4 c M$ & $57.4 c M$ \\
\hline \multicolumn{8}{|l|}{ Sample } \\
\hline Control & ND & 208 & 259 & 263 & 181 & 271 & 163 \\
\hline Control & 246 & 210 & 259 & 263 & 173 & 277 & 161 \\
\hline Control & 250 & 218 & 259 & 263 & 181 & 281 & 163 \\
\hline Control & 248 & 218 & 265 & 269 & 183 & 279 & 161 \\
\hline Control & 244 & 218 & 259 & 263 & 185 & 281 & 171 \\
\hline Control & 248 & 204 & 269 & 259 & 181 & 279 & 161 \\
\hline Control & 248 & 212 & 261 & 263 & 179 & 281 & 163 \\
\hline Control & 246 & 210 & 259 & 259 & 181 & 281 & 163 \\
\hline Control & 248 & 210 & 267 & 265 & 173 & 281 & 163 \\
\hline Control & 244 & 216 & 259 & 259 & 173 & 275 & 161 \\
\hline 130008 & 244 & 204 & 271 & 263 & 181 & 281 & 163 \\
\hline 320001 & 244 & 204 & 271 & 263 & 181 & 281 & 163 \\
\hline 160009 & 244 & 204 & 271 & 263 & 181 & 281 & 165 \\
\hline 200001 & 248 & 208 & 269 & 263 & 181 & 281 & 163 \\
\hline
\end{tabular}

All alleles given are in base pairs (bp) sized by M13mp18 sequence ladder

Marker positions are shown in cM. ND: Not determined 
Table 2: Clinical signs in CMTX1 patients with Ser26Trp mutation in the $\mathrm{Cx} 32$ gene

\begin{tabular}{lll}
\hline & $\begin{array}{l}\text { Males } \\
(\mathrm{N}=6)\end{array}$ & $\begin{array}{l}\text { Females } \\
(\mathrm{N}=10)\end{array}$ \\
$\begin{array}{l}\text { Distal muscle weakness } \\
\text { (upper or lower limbs) }\end{array}$ & $6(100 \%)$ & $3(30 \%)$ \\
$\begin{array}{l}\text { Distal muscle wasting } \\
\text { (upper or lower limbs) }\end{array}$ & $6(100 \%)$ & $2(20 \%)$ \\
$\begin{array}{l}\text { Distal sensory loss } \\
\text { (upper or lower limbs) }\end{array}$ & $3(50 \%)$ & \\
- Pain and touch & & \\
- Proprioception & $6(100 \%)$ & $8(80 \%)$ \\
$\begin{array}{l}\text { Reflexes retained } \\
\text { - Knee/biceps }\end{array}$ & $4(67 \%)$ & \\
- Ankle & $0(100 \%)$ & $9(90 \%)$ \\
Foot deformities & $6(100 \%)$ & $5(50 \%)$ \\
\hline
\end{tabular}

gel with the Bio-Rad Protean Cell system (Bio-Rad laboratories) for five hours under constant $300 \mathrm{~V}$ at $6^{\circ} \mathrm{C}$. DNAwas stained by ethidium bromide $(0.2 \mathrm{mg} / \mathrm{ml})$ and fragments were observed by fluorescent transillumination. The mutation was then identified by sequencing of the PCR product on Applied Bio-instruments automatic sequencer 377 (Perkin-Elmer Corporation).

\section{Haplotype analysis}

Microsatellite markers were chosen from the $7.5 \mathrm{cM}$ CMTX interval defined by Le Guern et al. ${ }^{19}$ The marker positions were taken from the Marshfield Medical Research Map database (www.marshmed.org/genetics) and primer sequences were obtained from published databases (genome database: www.gdb.org).

The markers examined were DXS1216, DXS1275, DXS8031, DXS8046, DXS983, DXS8092 and DXS986. The DNAsamples analyzed included one affected male from each of the four Ser26Trp families, and 10 unrelated, unaffected, male French-Canadian controls. Marker alleles were amplified by PCR that incorporated ${ }^{35} \mathrm{~S}$-labeled ATP. PCR products were separated by electrophoresis on acrylamide-urea sequencing gels and were visualized by autoradiography. Allele sizes were determined by means of a sequencing ladder.

\section{RESUlTS}

\section{Molecular analysis}

Of the 105 families with a clinical CMT phenotype, 78 families have a clinical CMT type I syndrome and 25 families a CMT type II syndrome. Twenty-three (23) of these 78 families had no chromosome 17 DNA duplication. The families with a clinical history compatible with a CMTX (no male to male transmission, females less affected than males, mildly reduced
MNCVs) were then screened for mutations in the coding region of the $\mathrm{C} \chi 32$ gene by nonisotopic single strand conformation polymorphism. We also screened CMT II families with a clinical history compatible with CMTX. A missense mutation, a $\mathrm{C}$ to $\mathrm{G}$ transition at amino acid 26 (serine to tryptophan) was found in four families and another missense mutation, a $\mathrm{C}$ to $\mathrm{T}$ at amino acid 142 (arginine to tryptophan) was found in one other family. These mutations cosegregate with the disease and were not found in 30 unrelated normal DNA samples. Because the four families with the Ser26Trp mutation originated from the same region of the province of Quebec (area of Portneuf), we next looked at a possible founder effect (Table 1). The four families with the Ser26Trp mutation all shared a core 263/181/281 haplotype. In addition, three of the families shared an extended haplotype that included at least six markers spanning $3.8 \mathrm{cM}$ flanking the CMTX locus, while the fourth family shared one additional allele with the extended haplotype.

\section{Prevalence of CMTX in Quebec}

Seventy families with hereditary motor and sensory neuropathy were detected within a defined area (center of Quebec) of the province of Quebec. The prevalence of hereditary motor and sensory neuropathy was 11.8 cases per 100,000 . The prevalence of CMTX was 0,8 per 100,000 and accounts for $7 \%$ of all CMT cases.

\section{Clinical features of patients with a Ser26Trp mutation.}

Of the 16 patients from four families with a mutation at Ser26Trp, 6 were males and 10 females. Their mean age at time of examination and DNA testing was $39.5 \pm 12.5$ (mean \pm SD) for the total sample, $39.2 \pm 13.4$ (range, 20-53) and $39.7 \pm 12.8$ (range 20-53) for males and females, respectively. A positive family history consistent with $\mathrm{X}$ dominant inheritance was present in the four families. In seven individuals the age at onset was impossible to establish because they were diagnosed at the examination. For the other individuals, the mean age at onset was $10.5 \pm 4.1$ years.

The summary of the clinical feature is shown in Table 2 . Affected males had a more severe phenotype than affected females. The classical CMT syndrome, namely distal muscle weakness, atrophy, areflexia, and foot deformities (pes cavus) was only observed in a 20 - and 25 -year-old male $(12.5 \%$ of cases). The most consistent clinical symptoms were foot deformities (100\% of male cases and $90 \%$ of female cases), deep sensory loss in the lower limbs $(100 \%$ of male cases and $80 \%$ of female cases), and ankle jerk areflexia (100\% of male cases and $50 \%$ of female cases). The mean age of males with foot deformities, deep sensory loss in the lower limbs and ankle jerk areflexia was $45.2 \pm 4$ years. One female (6.5\% of cases) had only foot deformities and another $(6.5 \%$ of cases $)$ was clinically asymptomatic.

The functional handicap was assessed according a nine-point functional disability scale (FDS). Functional disability was mild or absent (scale 0,1$)$ in 12 patients $(75 \%)$; two patients $(12.5 \%$ ) were at stage 2 ; and two patients $(12.5 \%)$ were at stage 3 or 4 . The functional disability was more severe in males $(2 \pm 1.4$ mean $\pm \mathrm{SD}$, range $0-4)$ than in females $(0.4 \pm 0.5$, range $0-1)$.

The median nerve conduction velocity was significantly more reduced in males $(29 \pm 4.8 \mathrm{~m} / \mathrm{s}$, range $22-33)$ than in females (49 $\pm 6 \mathrm{~m} / \mathrm{s}$, range 41-57) (Table 3). Distal median motor latency was 
Table 3: Motor nerve conduction findings in CMTX1 patients with Ser26Trp mutation in the Cx32 gene

\begin{tabular}{lcccc}
\hline & $\begin{array}{c}\text { Present study } \\
\text { Males } \\
(\mathrm{N}=5)\end{array}$ & $\begin{array}{c}\text { Females } \\
(\mathrm{N}=9)\end{array}$ & $\begin{array}{c}\text { From Birouk et al } \mathbf{I}^{\mathbf{1 4}} \\
\text { Males } \\
(\mathrm{N}=21)\end{array}$ & $\begin{array}{l}\text { Females } \\
(\mathrm{N}=27)\end{array}$ \\
Median nerve & & & & $44 \pm 7.3(31$ to 55$)$ \\
$-\mathrm{MNCV}(\mathrm{m} / \mathrm{s})$ & $29 \pm 4.8(22$ to 33$)$ & $49 \pm 6(41$ to 57$)$ & $36.2 \pm 6.7(31$ to 60$)$ & $3.9 \pm 2.4(0.8$ to 9.7$)$ \\
$-\mathrm{CMAP}(\mathrm{mV})$ & $2.0 \pm 2.2(0.3$ to 6$)$ & $6.5 \pm 3.3(3.7$ to 13$)$ & $2.6 \pm 1.8(0.3$ to 6.3$)$ & $3.8 \pm 0.9(2.7$ to 6.2$)$ \\
- DML(ms) & $7.0 \pm 0.9(6.6$ to 7.7$)$ & $5.5 \pm 0.9(3.5$ to 6.3$)$ & $4.7 \pm 1.1(2.3$ to 7$)$ & 1 \\
No response & 1 & 0 & 1 &
\end{tabular}

$\mathrm{MNCV}=$ motor nerve conduction velocity; $\mathrm{CMAP}=$ compound muscle action potential; $\mathrm{DML}=$ distal motor latency.

Median nerve conduction velocities were not available for one male and one female.

Laboratory control values for the median nerve were : MNCV $>48 \mathrm{~m} / \mathrm{s}$; CMAP $>4.2 \mathrm{mV}$; DML $<4.4 \mathrm{~ms}$.

prolonged in most patients (67\% of cases) and it was more prolonged in males $(7.0 \pm 0.9 \mathrm{~ms}$, range $6.6-7.7 \mathrm{~ms})$ than in females $(5.5 \pm 0.9 \mathrm{~ms}$, range $3.5-6.3 \mathrm{~ms})$. Distal compound muscle action potential amplitudes (CMAPs) were reduced in $58 \%$ of cases and were more reduced in males $(2.0 \pm 2.2 \mathrm{mV}$, range $0.3-6.0 \mathrm{mV})$ than in females $(6.5 \pm 3.3 \mathrm{mV}$, range 3.7 $13 \mathrm{mV})$. No response could be elicited in one female and one male. Regression analysis between distal motor latency and MNCVs for median nerve showed a significant positive correlation. Although the decrease in CMAPs parallel the decrease in MNCVs for median nerve, regression analysis showed no significant correlation, probably because of the small number of samples $(r=0.48)$. Similar results were obtained for the ulnar nerve conduction velocity, distal latency and muscle action potential.

Median sensory nerve conduction velocities were mildly reduced $(37.4 \pm 4.7 \mathrm{~m} / \mathrm{s}$, range 33 to 43$)$ in most cases whereas SNAPs $(24.9 \pm 16.2$, range 2.8 to $53 \mathrm{mcV})$ were normal in $80 \%$ of cases. SNAPs could not be recorded in one female and four males for the median nerve, indicating that the results of median sensory conduction velocities represent those obtained in females and in one male. Similar results were obtained for the ulnar nerve (not shown). In a majority of patients (85\% of cases) SNAPs could not be recorded for the sural nerve.

Needle EMG examination in the upper limbs showed a reduced recruitment pattern in $64 \%$ of cases. Fibrillation potentials were observed in $30 \%$ of cases and high-amplitude motor unit potentials were observed in $10 \%$ of cases. Four females had normal EMGs but an abnormal electrophysiological study. No needle examination was performed in the lower limbs.

\section{Discussion}

The minimum estimated prevalence of CMT (11.8 cases per 100,000 inhabitants) in a French-Canadian population does not differ from the frequency of CMT elsewhere in the world. ${ }^{20-22}$ The minimum prevalence of X-linked CMT in our FrenchCanadian population was estimated to be around 0.8 per 100,000 population and accounts for $7 \%$ of all CMT cases. The prevalence of CMTX in Quebec does not differ with the prevalence of X-linked CMT elsewhere in the world. ${ }^{23,24}$ It is of note that our study might suffer from a selection bias, given that the probands were referred from neuromuscular clinics. We can suspect that mildly affected families were underestimated and that the prevalence of CMTX is probably higher than that reported here. Furthermore, it is possible that families with mutations in the promoter region of the $\mathrm{C} \chi 32$ gene were undiagnosed since we only analyzed the coding region of the $\mathrm{C} \chi 32$ gene. A striking feature observed in the French-Canadian population is that the two mutations found in the $C \chi 32$ gene are rare in other populations. The Ser26Trp mutation, located in the transmembrane domain I of the $\mathrm{C} \chi 32$ gene, has not yet been reported and the Arg140Trp mutation, located in the transmembrane domain III of the $\mathrm{C} \chi 32$ gene, has only been reported in one family in the United States. ${ }^{1}$ These two mutations cosegregate with the disease and were not found in normal chromosomes, indicating that they do not represent nonpathogenic polymorphisms. Haplotype analysis revealed that the four families with the Ser26Trp mutation share a large region of the $\mathrm{X}$ chromosome, suggesting a common origin. A founder effect would explain the fact that we found four families with this rare mutation.

The clinical and electrophysiological manifestations in families with $\mathrm{C} \chi 32$ mutations have been recently reported. ${ }^{6,15}$ These studies do not, however, precisely correlate the clinical features with the position of the mutations in the $\mathrm{C} \chi 32$ gene. Because the four French-Canadian families have the identical Ser26Trp mutation, we examined the clinical features in these kindreds. The most consistent signs are deep sensory loss in the lower limbs, ankle areflexia and foot deformities. It is of note that the two patients with a classical CMTsyndrome are younger than those with a partial CMT syndrome indicating that the complete CMT syndrome is not the result of a more advanced neuropathy. These clinical manifestations did not differ from those reported for other patients with different mutations. ${ }^{6,13,15,16}$ These results together suggest that no specific phenotype is associated with Ser26Trp genotype.

There is controversy as to whether CMTX is a demyelinating or axonal neuropathy. A recent study shows that patients with CMTX had reduced CMAP associated with normal MNCV suggesting a primary axonal defect. ${ }^{15} \mathrm{~A}$ similar conclusion has been reported by Hahn et al. ${ }^{25}$ Other studies have shown that the 
most severely affected males had very slow conduction which was associated with reduced median motor nerve CMAPs, a fact that cannot be explained solely by axon loss. ${ }^{26,27}$ Here we show that three of the 16 patients with reduced MNCV have normal CMAPs and reduced CMAPs were associated with severe reduced MNCVs. We also did not observe patients with reduced CMAPs and normal MNCVs. Finally, we also showed that SNAPs were normal in most of the patients whereas sensory conduction velocities were reduced in these patients. These results together are consistent with a primary demyelinating process in patients with Ser26Trp mutation.

The pathophysiological basis of CMTX remains unknown. The effect of a mutation (Ser26Leu) most similar to that found in our families has been shown to reduce the pore diameter from 7A for the wild type channel to less than $3 \mathrm{~A}$ for Ser26Leu. ${ }^{28} \mathrm{Oh}$ et $\mathrm{al}^{29}$ speculate that this mutation may lead to loss of function by inducing changes in the pore which make the channel impermeable to signaling molecules. The Ser26Trp mutation identified in our families may produce a similar effect. It is possible that Ser26Trp mutation may restrict the passage of important molecules that are essential for Schwann cell survival, leading to a demyelinating neuropathy. However, given that other types of mutations, like Arg22Stop, produce axonal loss with secondary demyelination, we cannot be certain of the effects of our Ser26Trp mutation. Further studies on the functional consequences of specific mutations on nerve conduction velocities will help in our understanding of the role of these $\mathrm{C} \chi 32$ mutations on nerve function.

\section{ACKNOWLEDGMENTS}

We thank the participating CMT families. The contribution provided by Mrs Lise Dumas from the "Institut de Réadaptation en Déficience Physique du Québec" (IRDPQ) is also acknowledged. This study was supported by the "Consortium en Réadaptation de l'Est du Québec". GAR is supported by the Medical Research Council of Canada.

\section{REFERENCES}

1. Bergoffen J, Scherer SS, Wang S, et al. Connexin mutations in Xlinked Charcot-Marie-Tooth disease. Science 1993; 262: 20392042.

2. Nelis E, Haites N, Van Broeckhoven C. Mutations in the peripheral myelin genes and associated genes in inherited peripheral neuropathies. Hum Mutat 1999;13:11-28.

3. Chance PF, Bird TD, O'Connell P, et al. Genetic linkage and heterogeneity in type I Charcot-Marie-Tooth disease (hereditary motor and sensory neuropathy type I). Am J Hum Genet 1990; 47:915-925.

4. Fairweather N, Bell C, Cochrane S, et al. Mutations in the connexin 32 gene in X-linked dominant Charcot-Marie-Tooth disease. Hum Mol Genet 1994; 3:29-34

5. Bone LJ, Dahl N, Lensch MW, et al. New connexin 32 mutations associated with X-linked Charcot-Marie-Tooth disease. Neurology 1995; 45:1863-1866.

6. Ionasescu V, Ionasescu R, Searby C. Correlation between connexin 32 gene mutations and clinical phenotype in X-linked dominant Charcot-Marie-Tooth neuropathy. Am J Med Genet 1996; 14:486-491.

7. Ressot $\mathrm{C}$, Latour $\mathrm{P}$, Blanquet Grossard $\mathrm{F}$, et al. X-linked dominant Charcot-Marie-Tooth neuropathy (CMTX): new mutations in the connexin32 gene. Hum Genet 1996; 98: 172-175.

8. Tan CC, Ainsworth PJ, Hahn AF, MacLeod PM. Novel mutations in the connexin gene associated with X-linked Charcot-Marie-Tooth disease. Hum Mutat 1996; 7: 167-171.
9. Janssen EA, Kemp S, Hensels GW, et al. Connexin 32 gene mutations in X-linked dominant Charcot-Marie-Tooth disease (CMTX1). Hum Genet 1997; 99:501-505

10. Rouger H, Le Guern E, Birouk N, et al. Charcot-Marie-Tooth disease with intermediate motor conduction velocities: Characterization of 14 CX32 mutations in 35 families. Hum Mutat 1997; 10: 443-452.

11. Silander K, Meretoja P, Pihko H, et al. Screening for connexin 32 mutations in Charcot-Marie-Tooth disease families with possible X-linked inheritance. Hum Genet 1997; 100: 391-407.

12. Philips LH, Kelly TE, Schnatterly P, Parker D. Hereditary motorsensory neuropathy (HMSN): possible X-linked dominant hereditance. Neurology 1985; 35: 498-502.

13. Nicholson G, Nash J. Intermediate nerve conduction velocities define X-linked Charcot-Marie-Tooth neuropathy families. Neurology 1993; 43: 2558-2564.

14. Ionasescu V, Searby C, Ionasescu R, Meschino W. New point mutations and deletions of the connexin 32 gene in X-linked Charcot-Marie-Tooth neuropathy. Neuromuscul Disord 1995; 5: 297-299.

15. Birouk N, LeGuern E, Maisonobe T, et al. X-linked Charcot-MarieTooth disease with connexin 32 mutations: clinical and electrophysiologic study. Neurology 1998; 50: 1074-1082.

16. Hahn A, Bolton CF, White CM, et al. Genotype/phenotype correlations in X-linked dominant Charcot-Marie-Tooth. In: Shy ME, Kamholz J and Lovelace RE, eds. Charcot-Marie-Tooth Disorders, NYAcad Sci, 1999; 883:366-382.

17. Birouk N, Gouider R, Le Guern E, et al. Charcot-Marie-Tooth disease type $1 \mathrm{~A}$ with $17 \mathrm{p} 11.2$ duplication. Clinical and electrophysiological phenotype study and factors influencing disease severity in 119 cases. Brain 1997; 120: 813-823.

18. Dupré N, Bouchard JP, Cossette L, et al. Clinical and electrophysiological study in French-Canadian population with Charcot-Marie-Tooth disease type 1A associated with $17 \mathrm{p} 11.2$ duplication. Can J Neurol Sci, 1999;26:196-200.

19. Le Guern E, Ravise N, Gugenheim M, et al. Linkage analyses between dominant X-Linked Charcot-Marie- Tooth disease, and $15 \mathrm{Xq} 11-\mathrm{Xq} 21$ microsatellites in a new large family: three new markers are closely linked to the gene. Neuromuscul Disord 1994; 4: 463-469.

20. MacMillan JC, Harper PS. Single-gene neurological disorders in South Wales: an epidemiological study. Ann Neurol 1991;30:411414.

21. Combarros O, Calleja J, Polo JM, Berciano J. Prevalence of hereditary motor and sensory neuropathy in Cantabria. Acta Neurol Scand 1987;75:9-12.

22. Holmberg BH. Charcot-Marie-Tooth disease in northern Sweden: an epidemiological and clinical study. Acta Neurol Scand 1993;87:416-422.

23. Baraitser $M$. The genetics of neurological disorders. 2nd ed. Motulsky AG, Bobrow MB, Harper PS, Scriver C, eds. Oxford Monographs on Medical Genetics, vol 18. Oxford, UK: Oxford University Press, 1990:238-239.

24. Silander K, Meretoja P, Juvonen V, et al. Spectrum of mutations in Finnish patients with Charcot-Marie-Tooth disease and related neuropathies. Hum Mutat 1998;12:59-68.

25. Hahn AF, Brown WF, Koopman WJ, Feasby TE. X-linked dominant hereditary motor and sensory neuropathy. Brain 1990;113:15111525.

26. Gutierrez A, England JD, Summer AJ, et al. Unusual electrophysiological findings in X-linked dominant CharcotMarie-Tooth disease. Muscle Nerve 2000;23:182-188.

27. Tabaraud F, Lagrange E, Sindou P, et al. Demyelinating X-linked Charcot-Marie-tooth disease: unusual electrophysiological findings. Muscle Nerve 1999;22:1442-1447.

28. Abrams CK, Oh S, Ri Y, Bargiello TA. Mutations in connexin 32: the molecular and biophysical bases for the X-linked form of Charcot-Marie-Tooth disease. Brain Res Rev 2000;32:203-214.

29. Oh S, Ri Y, Bennett MV, et al. Changes in permeability caused by connexin 32 mutations underlie X-linked Charcot-Marie-Tooth disease. Neuron 1997;19:927-938. 